\title{
Centrosomes in Fertilization Stages of Preissia quadrata (Scop.), Nees.
}

\author{
BY
}

\section{MARGARET GRAHAM.}

\section{With Plate $\mathbf{X}$.}

SO far as the evidence in the literature on the subject goes, it seems clear $\infty$ that while centrosomes are present in the nuclear division figures of many algae and fungi, they are just as regularly absent from nuclear division figures in the higher plants. In both, however, they are active as blepharoplasts in connexion with the formation of cilia. There is very little evidence as to whether centrosomes are present during the stages of fertilization in plants, though in animals it is fairly well established that, in many cases at least, the centre which has been brought into the egg by the sperm divides in the formation of the cleavage spindle. In the Bryophytes and Pteridophytes, in a number of cases, the centre which becomes the blepharoplast is described as arising by division from a centre which has appeared at the poles of the karyokinetic figure in the last preceding division or in several of the preceding nuclear divisions. No one has, however, followed the centre through the processes of fertilization in these forms. As is described below, I have been able to demonstrate that in Preissia quadrata centres are present at the time when the pronuclei come together.

It is not to be forgotten that evidence has accumulated that structures at least closely simulating centrosomes in appearance can be produced artificially in the cytoplasm of eggs stimulated with chemicals.

As a result of stimulating the egg-cells of Strongylocentrotus lividus at various stages, Hertwig (1887) observed artificial astrospheres in the cytoplasm, sometimes isolated and sometimes associated with chromosomes. The astral rays of these artificial astrospheres of Hertwig are said to radiate from a clear area in which there is no centrosome.

By stimulating the eggs with salt solutions Morgan (1899) induced astrosphere-formation also in the cytoplasm of the unfertilized eggs of Arbacia. These artificial astrospheres of Morgan centre on a dense body. Morgan also observed many astrospheres with clear centres similar to those

[Annals of Botany, Vol, XXXII. No. CXXVII. July, Igr8.] 
described by Hertwig. And artificial astrospheres (cytasters), some with a clear centre, others with a granule on which rays centre, were observed by Wilson (1901) in the stimulated cytoplasm of unfertilized eggs of Toxopneustes variegatus.

Central bodies and asters in the Algae are apparently related to cell and nuclear division in the same fashion as in animals. Radiations were observed by Farmer and Williams (1896-7) at opposite poles of the oogonial nucleus and also from the cleavage nucleus in Fucus vesiculosus; and in the germination of the oosphere of the same plant granules that stand at the centre of a ray system were observed by the same workers (1898). Two such systems are described as forming the poles of the fully formed spindle appearing during the prophases and persisting through the anaphases. Strasburger $(1896-7)$ observed in $F$. serratus that two centrosomes with their radiations lie on the nuclear membrane of the fusion nucleus as it enters the anaphases. They lie on the margin of the fusion area of the two sexual nuclei, he points out, and form the poles of the fully formed spindle. Swingle (1897) observed fibres that radiate from definite small points at the poles of the nucleus in Stypocaulon. These systems, it is claimed, originate from a granule lying on the nuclear membrane; and kinoplasmic threads from the same centrosomes enter the nuclear cavity, become attached to the chromosomes, and form the spindle. A rod-shaped centrosome on opposite poles of the nucleus and at the centre of diverging rays was observed in Dictyota dichotoma by Mottier (1900). Mottier also states that fibres penetrate the nuclear membrane and that some of them become attached to chromosomes.

In the Fungi a relationship that exists between the chromatin and central body in Phyllactinia corylea during karyokinesis and the resting period was observed by Harper (1905). In addition to this relation to division Harper observed that centrospheres are concerned with delimiting. the mass of cytoplasmic substance about the nucleus of the forming ascospore.

The majority of recent authors, Hirasé (1898), Belajeff (1899), Ikeno (1903), Chamberlain (1903), Jahn (1904), and Allen (1912) seem to regard the blepharoplast as a modified central body.

Farmer (1895) has described the centrospheres in the dividing spore mother-cell of Pellia epiphylla as arising at four points on the nuclear membrane, points from which radiations extend into the lobe nearest it. A minute centrosome was observed within the centrosphere. It is in the Bryophytes that we may expect to find clues to the explanation of the relations between the method of spindle formation in the higher plants where centrosomes are not present and the method of spindle formation in the Algae, Fungi, and animals where centrosomes are commonly present. There is considerable evidence that centrosomes are present in the vegetative divisions of the cells of Liverworts. In the germinating spore of Pellia 
epiphylla Farmer and Reeves (1894) describe two minute structures on opposite sides of the nucleus in contact with its membrane. Radiations extend from these structures into the cytoplasm and later over the nuclear membrane; and as the latter disappears, the spindle is formed. At opposite poles of the elongated nucleus of cells in the stalk of the archegoniaphore of Marchantia polymorpha van Hook (1900) observed a body from which radiations extend, some of which penetrate the nuclear membrane. Kinoplasmic radiations in the germinating spore of Pellia epiphylla have been described by several investigators, first by Farmer and Reeves (1894). Farmer (1895) described them as radiating either from a minute centrosome or from a group of granules outside of which is a hyaline space. Davis (1901) observed asters that radiate from a vague centrosphere-like region at opposite sides of the nucleus. Chamberlain (1903) observed caps at the poles of the nucleus that become resolved into fibres; and Grégoire and Berghs (1904) describe cytoplasmic fibres oriented on the poles of the nucleus either on a polar vesicle or on the nuclear membrane, which radiate towards the cell membrane or towards the equatorial plane enveloping the nucleus. The aster is described as a cytoplasmic network, the rays of which are joined among themselves. Both centrospheres and centrosomes are said to be absent. In the Mosses Allen (1912) observed plates of kinoplasm that occupy opposite sides of the nucleus of the antheridial cells of Polytrichum juniperinum. These kinoplasmic plates are formed by the division of a single plate into two daughter plates, and are connected by fibres. In later divisions the kinoplasmic plates are replaced by bodies, and finally by a central body.

I have studied the process of fertilization in Preissia quadrata at a stage when the nucleus of the antherozoid lies near the centre of the egg. My material was collected from gorges around Ithaca and prepared for sectioning at Cornell University. I am indebted to Prof. G. F. Atkinson for the privileges of the botanical laboratory there, where for several years I experimented with methods of handling the plants and with various killing reagents. The material from which drawings were made for this article was killed in the field in a modified Flemming solution. I also acknowledge the privileges of the laboratory in the Cornell Medical College at Ithaca. My material was stained and studied at the botanical laboratory at Columbia University and examined by Prof. R. A. Harper, to whom I am indebted for a critical examination of my preparations.

Fertilization stages in Riella Clausonis have been described by Dr. Osvaldo Kruch, who reports that he saw many eggs with one antherozoid in the cytoplasm. Both nuclei, before fusion, were approximately of the same size. The male nucleus is said to contain eight chromosomes, as does also the egg nucleus. Fusion of the pronuclei was not observed, nor were astral rays and centrosomes. 
In the present paper I shall describe only the stages after the egg has been penetrated by the antherozoid, when the pronuclei are already near together or in contact (Pl. X, Figs. I, 3). During these stages the cytoplasm of the egg of Preissia quadrata is plainly made up of two zones. The inner zone is granular, with rounded bodies forming a dense aggregate that lies in masses around the pronuclei and among the rays of the centrospheres. A small amount of the same material also clings to the cytoplasmic fibres at the periphery of the cell (Figs. I, 3, 4). This dense cytoplasm may appear more or less alveolar at this stage. Prior to fertilization the whole cytoplasm of the egg has this consistency and is quite dense. The outer zone of the cytoplasm is coarsely vacuolar. The films between the vacuoles are very thin and delicate. A few larger and quite dense homogeneous granules are scattered through both zones of the cytoplasm. Between the nucleus of the antherozoid and the egg nucleus lies a small mass or body unlike the cytoplasm just described. From its position in close proximity to the nucleus of the antherozoid, the small quantity visible, and the absence of similar cytoplasm anywhere else in the cell, it might be thought to be cytoplasm brought in by the antherozoid, but I have no proof that this is the case. The egg and male nuclei are plainly differentiated by their size and in Fig. 3 lie in the central part of the cell, separated by a very little cytoplasm. In Fig. I their membranes are in contact.

In the cytoplasm at the opposite poles of the egg nucleus astral rays are seen converging upon small, dense, rounded bodies, the centrosomes (Figs. I, 3, 4, 6). These rays extend long distances through the cytoplasmic ground substance. They may pass close to the nuclear membrane or may touch it. A fibre radiating from the centrosome at the upper part of Fig. I touches the nuclear membrane of the antherozoid; another radiating from the same centrosome touches the outer membrane of the egg nucleus. These astral rays make up an open aster with few rays; but they are very definite, coarse, granular fibres, easily distinguishable from other cytoplasmic fibres. Peripherally they end rather abruptly and have no conspicuous physical connexion with any of the other elements of the dense cytoplasm. It is quite possible that there are other shorter and more delicate rays, but I have drawn only those which are plainly differentiated. In the fewness of their rays these asters resemble those described and figured by Farmer in the spore mother-cells of Pellia epiphylla. Figs. 4 and 6 represent two sections of an egg-cell on either side of the nucleus. The centrosphere shows advantageously in Fig. 4, in which some of the definite, coarse astral rays lie over the nuclear membrane, which is almost free of all other cytoplasmic material, while others extend into the dense alveolar cytoplasm. All these fibres centre on a centrosome, which seems to be a single body. In the section on the other side of the nucleus the centrosphere lies farther away from the nucleus, all of the astral rays running 
through dense alveolar cytoplasm (Fig. 6). No well-defined hyaline zone around the centrosome was recognizable at this stage. The region towards which the fibres converge varies in appearance. It has been variously described as a protoplasmic structure of minute size without a centrosome (Farmer and Reeves, 1894); a hyaline sphere containing a centrosome in its centre (Farmer, 1895); a centrosphere-like region of dense protoplasm, the interior of which is frequently granular (Davis, 1901); and a body consisting of the same substance as the astral rays (Chamberlain, 1903). Fig. I shows the nuclear membrane of the egg somewhat drawn out to a point where the centrosome lies upon it. The egg nucleus is thus apparently responding to the influence of the centrosphere at one pole. The nucleus of the antherozoid has progressed in the cytoplasm of the egg so that it lies partly beneath the nuclear membrane of the egg nucleus. Two of the rays from the centrosphere nearest it touch its membrane.

Centrosomes and asters are readily demonstrable in the sporophyte of $P$. quadrata. Fig. 7 represents a four-celled embryo. Part of the nucleus and the other centrosphere of each cell are in another section.

From my studies it is evident that centrosomes as definite granular bodies are present not only in the divisions just preceding spermatogenesis and, as blepharoplasts, during metamorphosis, but also in the fertilized egg at the time when the pronuclei are paired. I have further observations soon to be published on the behaviour of the centres during the earlier stages of the fusion of the antherozoid with the egg.

\section{LITERATURE CITED.}

Allen, Charles E.: Cell Structure, Growth, and Division in the Antheridia of Polytrichum juniperinum. Archiv für Zellforschung, Bd. viii, I. Heft, pp. I2I-78. I 1912.

BelajefF, W.: Ueber die Centrosome in den spermatogenen Zellen. Ber. d. Deutsch. Bot。 Gesellsch., Bd. xvii, pp. 199-204. 1899.

Chamberlain, Chas. J. : Mitosis in Pellia. Bot. Gaz., vol. xxxvi, pp. 28-50. 1903.

Davis, Bradley Moore: Nuclear Studies on Pellia. Ann. of Bot., vol. xv, pp. I47-80. I90I.

Farmer, J. Bretland : On Spore Formation and Nuclear Division in the Hepaticae. Ann. of Bot., vol. ix, pp. 469-52I. 1895 .

and Reeves, Jesse: On the Occurrence of Centrospheres in Pellia epiphylla, Nees. Ann. of Bot., vol. viii, pp. 219-24. 1894.

and Williams, J. LL.: On Fertilization and the Segmentation of the Spore in Fucus. Proc. Roy. Soc., London, vol. lx, pp. I88-95. $1896-7$.

caceae : their Life-history and Cytology. Phil. Trans. Roy. Soc., London, vol. cxc, series $\mathrm{B}, \mathrm{I} 898$.

GréGOIRe, Victor, et BerGhs, Jules: La figure achromatique dans le Pellia epiphylla. La Cellule, tom. xxi, $1^{\text {er }}$ fasc. 1904 . 
HARPER, R. A.: Sexual Reproduction and the Organization of the Nucleus in Certain Mildews. Carnegie Inst., Washington. 1905 .

HERTWIG, OSCAR und RICHARD : Über den Befruchtungs- und Teilungsvorgang des tierischen Eies unter dem Einfluss äusserer Agentien. Jen. Zeitschr., vol. xx. I887.

Hirasé, S. : Études sur la fécondation et l'embryogénie du Ginkgo biloba (Second Mémoire). Journ. Coll. Sci. Tokyo, vol. xii. 1898 .

IKeno, S. : Beiträge zur Kenntnis der pflanzlichen Spermatogenese. Die Spermatogenese von Marchantia polymorpha. Beih. z. Bot. Centralbl., Bd. xv, pp. 65-87. I903.

JAHN, E.: Myxomycetenstudien. 3. Kerntheilung und Geisselbildung bei den Schwärmern von Stemonitis flaccida, Lister. Ber. d. Deutsch. Bot. Gesellsch., Bd. xxii, pp. 84-9I. I904.

Kruch, Osvaldo : Appunti sullo sviluppo degli organi sessuali e sulla fecondazione della Riella Clausonis. Malpighi, vol. iv, pp. 403-30. 1890.

Morgan, T: H.: The Action of Salt Solutions on the Unfertilized and Fertilized Eggs of Arbacia and of other Animals. Archiv f. Entwickelungsmechanik d. Organismen, Bd. viii, 3. Heft, pp. $449-52 \%$. 1899 .

Mottier, David, M. : Nuclear and Cell Division in Dictyota dichotoma. Ann. of Bot., vol. xiv, pp. 163-92. 1900.

Strasburger, Eduard: Kerntheilung und Befruchtung bei Fucus. Jahrb. f. wiss. Bot., Bd. $\mathrm{xxx}, \mathrm{pp} .35^{\mathrm{I}-72}$. I896-7.

Swingle, W. T.: Zur Kenntnis der Kern- und Zelltheilung bei den Sphacelariaceen. Jahrb. f. wiss. Bot., Bd. xxx, Hefte 2 u. 3, pp. 297-346. I 897 .

van Hook, J. M.: Notes on the Division of the Cell and Nucleus in Liverworts. Bot. Gaz, vol. $\mathrm{xxx}, \mathrm{pp} .394^{-8} .1900$.

Wilson, E. B. : A Cytological Study of Artificial Parthenogenesis in Sea-Urchin Eggs. Archiv f. Entwickelungsmechanik d. Organismen, Bd. xii, 4. Heft, pp. 529-88. 1901.

\section{EXPLANATION OF FIGURES ON PLATE X.}

Illustrating Miss Graham's paper on Centrosomes in Fertilization Stages of Preissia quadrata.

The figures were drawn with the aid of a Bausch and Lomb camera lucida, the drawing being at the level of the base of the microscope; Zeiss $1.8 \mathrm{~mm}$. oil-immersion objective, $\mathbf{I}^{\circ}{ }_{5} \mathrm{~N}$.A., and oc. 4. Magnification about I43I $x$.

Fig. I. Section of the egg-cell. The membranes of the egg and antherozoid nuclei are in contact. Centrospheres lie at the poles of the egg nucleus.

Fig. 2. The contents of the egg nucleus of Fig. I.

Fig. 3. Section of the egg-cell in which the nucleus of the antherozoid lies in the cytoplasm near the egg nucleus. Centrospheres lie on either side of the egg nucleus.

Figs. 4, 6. Polar views of centrospheres lying on either side of the egg, and antherozoid nuclei shown in Fig. 5 .

Fig. 5. The egg and antherozoid nuclei situated between the centrospheres represented in Figs. $4,6$.

Fig. 7. Two cells of a four-celled embryo. Part of the nucleus and the other centrosphere of each cell are in another section. 

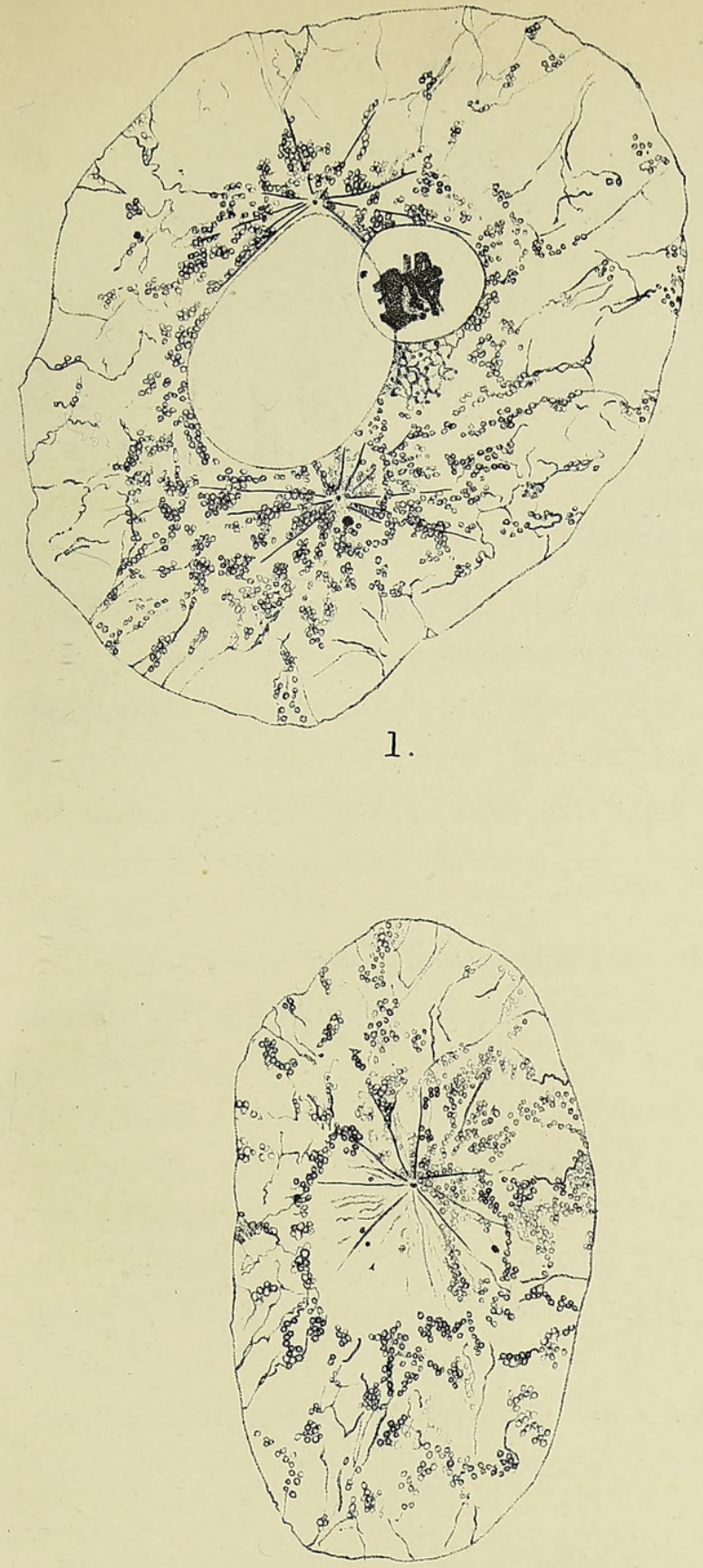

4.

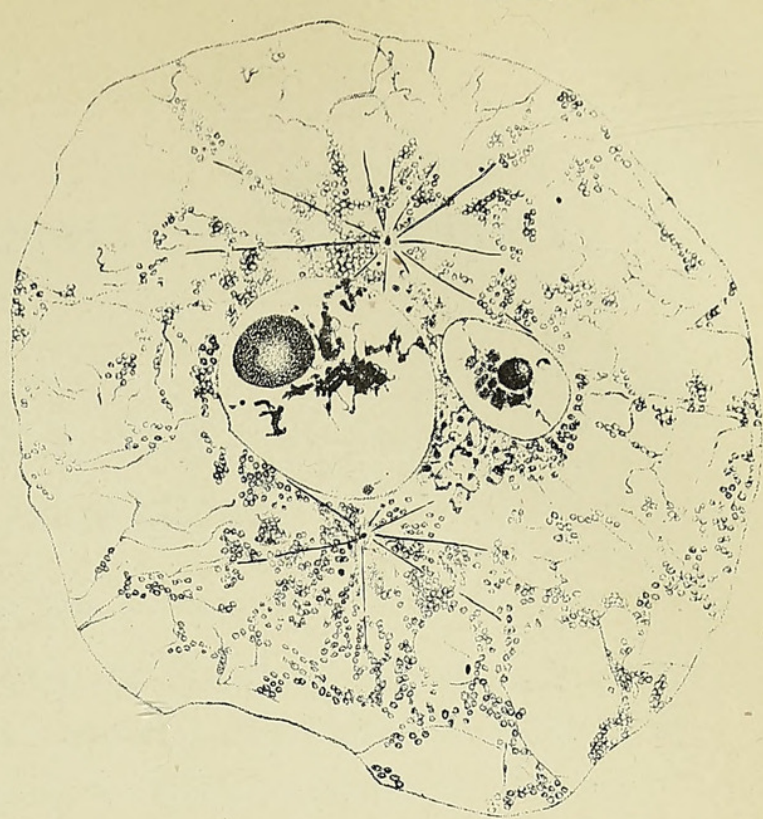

3.

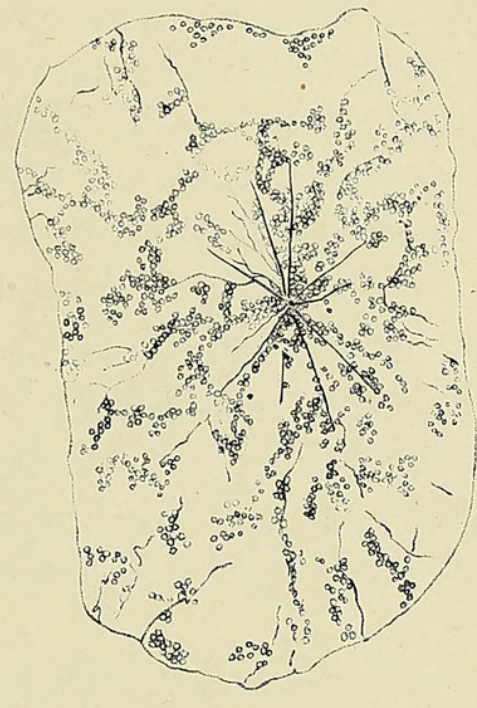

6.
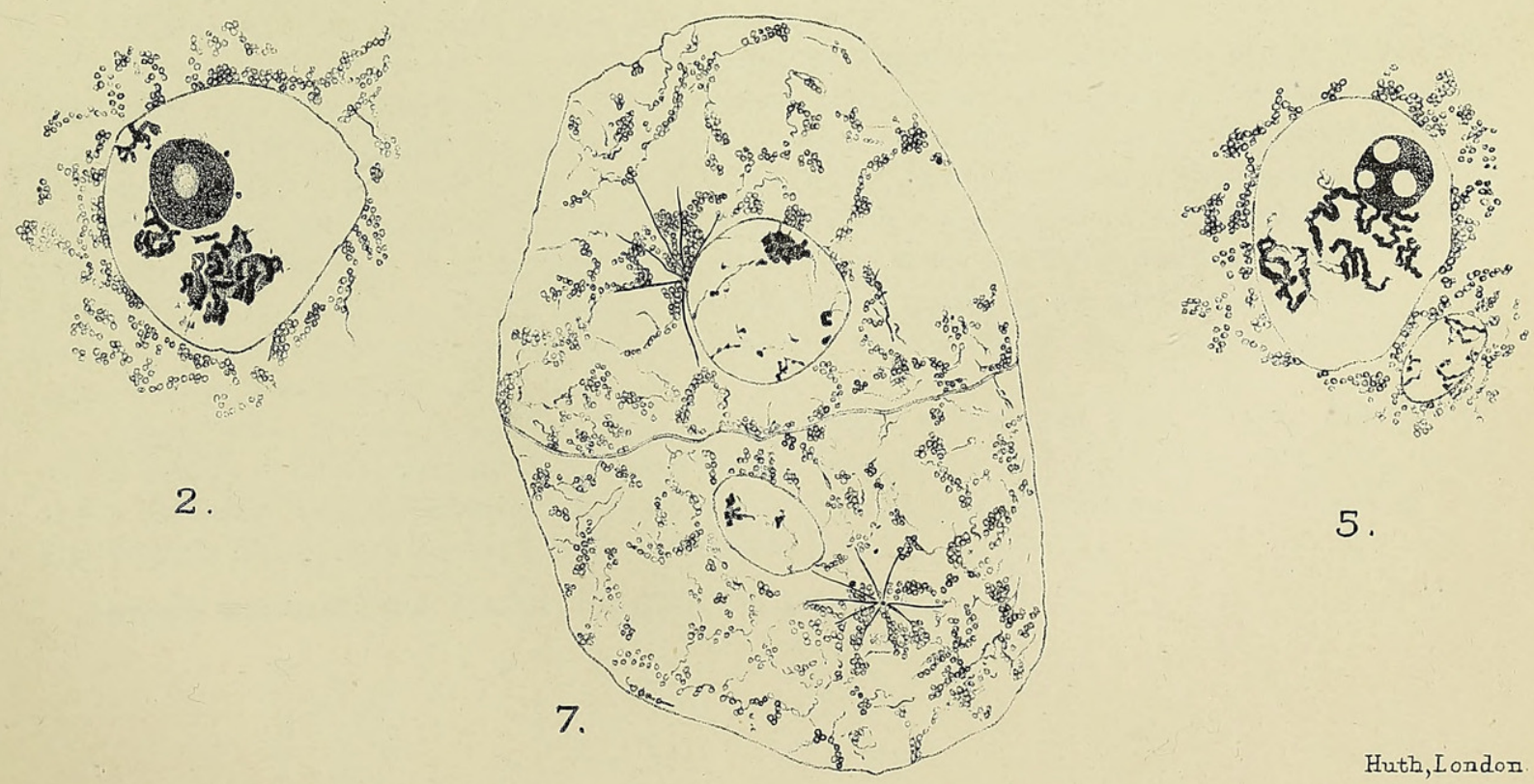

2. 


\section{$2 \mathrm{BHL}$ Biodiversity Heritage Library}

Graham, Margaret. 1918. "Centrosomes in fertilization stages of Preissia quadrata (Scop.), Nees." Annals of botany 32, 415-420.

https://doi.org/10.1093/oxfordjournals.aob.a089682.

View This Item Online: https://www.biodiversitylibrary.org/item/238284

DOI: https://doi.org/10.1093/oxfordjournals.aob.a089682

Permalink: https://www.biodiversitylibrary.org/partpdf/320225

\section{Holding Institution}

Smithsonian Libraries

\section{Sponsored by}

Biodiversity Heritage Library

\section{Copyright \& Reuse}

Copyright Status: Not in copyright. The BHL knows of no copyright restrictions on this item.

This document was created from content at the Biodiversity Heritage Library, the world's largest open access digital library for biodiversity literature and archives. Visit BHL at https://www.biodiversitylibrary.org. 